Egyptian

Orthodontic Journal

\title{
FOUR YEARS STABILITY EVALUATION OF THE CHANGES OBTAINED BY TWIN FORCE BITE CORRECTOR APPLIANCE
}

\author{
Atia Abd El Wareth Abd El Razik Yousif*
}

\section{ABSTRACT:}

Introduction: Class II malocclusion is one of the most frequent problems in orthodontics, as it affects one third of patients seeking orthodontic treatment. Fixed orthopedic appliances as twin force bite corrector (TFBC) and Jasper Jumper (JJ) appliance used for Treatment of Class II, division 1 malocclusion resulting in a mandibular advancement, Long-term stability following orthopedic correction of Class II malocclusion treatment is the fundamental key to a successful treatment outcome. Aim of the work: The objective of this study was to evaluate and compare the post retention stability of skeletal, dental, soft tissue and pharyngeal airway changes obtained with twin force bite corrector and jasper jumper after four years from the end of the treatment. Material and Methods: Two Lateral cephalometric $x$ - rays and two study models was compared for each patient treated with twin force bite corrector and jasper jumper (20 patients) one just after removal of the appliance at the end of treatment and the second one after four years of treatment. Results: All tested perimeters showed non significant difference after 4 years of treatment with TFBC appliance. Only the angular position of the upper incisors relative to FH plane and lower arch depth showed significant difference. Also upper arch depth showed significant

* Lecturer of Orthodontic, Faculty of Dentistry, Tanta University, Egypt 
difference. The changes obtained by IJ appliances seems to be less stable than TFBC appliance with little non significant difference between both groups. Conclusion: Both appliance results in stable skeletal, dental, soft tissue and pharyngeal airway changes with little non significant difference after 4 years of treatment.

Key Words: Twin Force Bite Corrector, Jasper Jumper, pharyngeal airway and developing class II division 1 malocclusion.

\section{INTRDUCTION}

Long-term stability following Class II malocclusion treatment is the fundamental key to a successful treatment outcome, and of prime concern for patients and orthodontists. Class II malocclusion is one of the most frequent problems in orthodontics, as it affects one third of patients seeking orthodontic treatment. ${ }^{(1)}$ Class II, division 1 malocclusion, involves maxillary dental and/or skeletal alterations. According to McNamara $\mathrm{JR}^{(2)}$ this malocclusion has a higher prevalence of mandibular retrusion in relation to maxillary protrusion. In such cases, the therapy of choice should include the use of facial orthopedic appliances resulting in a mandibular advancement, as long as the patient presents potential for craniofacial growth. ${ }^{(3)}$

Long-term stability following Class II malocclusion treatment is the fundamental key to a successful treatment outcome, and of prime concern for patients and orthodontists. ${ }^{(4,5)}$ Fixed functional orthopedic appliances are widely used, ${ }^{(6-9)}$ and can be worn in association with multi-bracket therapy, so that Class II malocclusion can be corrected in a single phase treatment. ${ }^{(10)}$ The twin force bite corrector is a recent appliance with ball and socket joint allowing jaws to move freely in all directions and Jasper Jumper appliance considered as one of the most popular flexible devices ${ }^{(11,12)}$ used for correction of class II division 1 malocclusion. 
Egyptian

Orthodontic Journal

Normally, orthodontic treatment takes a long time and uses complex techniques, usually achieving good results; however, these results may be lost in varying degrees after the removal of appliances and retainers. ${ }^{(13)}$ A major factor contributing to stability is the growth pattern of the patients $^{(14)}$. A favorable growth pattern, in addition to correct diagnosis, treatment, and retention protocols in motivated patients, probably increases the likelihood of stable long-term treatment results ${ }^{(15)}$. Orthodontic changes of the position of the first permanent molars have a great tendency to relapse. ${ }^{(16)}$ Besides growth, forces derived from the surrounding oro-facial tissues are believed to promote stability ${ }^{(17)}$. When dental changes are in harmony with the tongue and facial muscles, the result is thought to be more stable ${ }^{(18)}$.

Good occlusal inter-cuspation following Class II malocclusion treatment has been reported to be necessary to prevent skeletal and dental relapse $^{(18,19)}$. Nanda suggest good occlusion and cuspal inter-digitations, a constant inter-canine width, and no proclination of the lower incisors as some of the most important factors for long-term stability following orthodontic treatment ${ }^{(18)}$. Numerous studies and case reports have highlighted the effectiveness of fixed-functional appliances in correcting Class II malocclusion, but long-term analyses of the stability of these results have seldom been reported So the objective of this study was to evaluate and compare the post retention stability of skeletal, dental, soft tissue and pharyngeal airway changes obtained with twin force bite corrector and jasper jumper after four years from the end of the treatment.

\section{MATERIAL AND METHOD}

This study was carried out on 20 patients divided into two equal groups (10/each) and exhibiting developing Class II Division 1 malocclusion, indicated for functional appliance therapy and treated with Twin Force Bite Corrector and Jasper Jumper appliances four years ago in the Orthodontic Clinic at Orthodontic Department, Faculty of Dentistry, Tanta University. 
-Two series of lateral cephalometric x-rays and study models were made for each patient, one at the end of treatment just after removal of the appliance and a second one after four years to evaluate and compare the stability of skeletal, dental, soft tissue and pharyngeal airway changes produced by the $\mathrm{TFBC} *$ and $\mathrm{JJ}{ }^{\star}$ appliances.

Tracing of the radiographs and landmark identification were performed by the investigator and checked for accuracy after two weeks. Linear and angular measurements were recorded to the nearest $0.5 \mathrm{~mm}$ and 0.5 degree, respectively.

Angular Measurements: (figure 1 and 2)

1- SNA

2- SNB

3- ANB

4- $\mathrm{SN}-\mathrm{Pg}$

5- Facial angle

6- Frankfort horizontal plane to SN plane angle (FH-SN).

7- Upper incisor long axis to Frankfort horizontal plane angle (U1-FH).

8- Lower incisor long axis to mandibular plane angle (L1-MP).

9- Inter-incisal angle.

10- Angle formed by MP and SN.

11- Angle formed by MP and PP.

12- Angle formed by NB line and a line connecting the most anterior point of the upper lip and Pg soft tissue point (H angle).

13- The angle formed by the labial surface of the upper lip at the midline and the inferior border of the nose. (Naso-labial angle).

*Registered trademark of Ortho Organizers, 1822 Aston Ave., Carlsbad, CA 92008;

www.orthoorganizers.com.

- American Orthodontics, 1714 Cambridge Ave., Sheboygan, WI 53082 


\section{Egyptian}

Orthodontic Journal

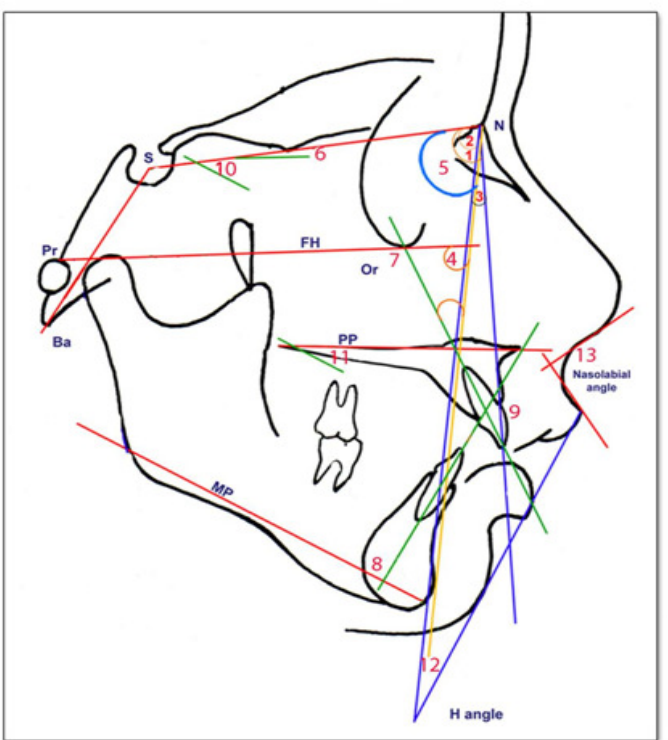

Figure 1 : Cephalometric points, lines, planes and angles.

$\begin{array}{ll}\text { 1- SNA } & \text { 8- L1-MP } \\ \text { 2- SNB } & 9 \text { - inter-incisal angle } \\ \text { 3-ANB } & \text { 10- MP-SN } \\ \text { 4- Facial angle } & \text { 11- MP-PP } \\ \text { 5- SN-Pg } & \text { 12- H-angle } \\ \text { 6- FH-SN } & \text { 13- Nasolabial angle } \\ \text { 7- U1 - FH } & \end{array}$

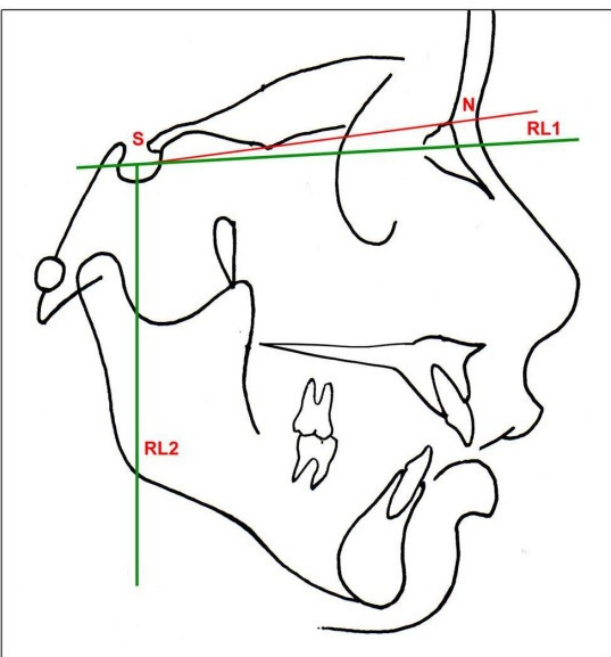

Figure (2): Horizontal and vertical reference planes RL1 and RL2. (Nalbangtil et al 2005) ${ }^{(20)}$ 


\section{Linear Measurments: (Figure 3)}

1. Upper anterior facial height (UAFH).

2. Lower anterior facial height (LAFH).

3. Total anterior facial height TAFH (N-Me).

4. Posterior facial height (PFH).

5. Overjet.

6. Overbite.

7. The distance from upper incisor tip to reference line RL1 (RL1-U1T).

8. The distance from lower incisor tip to reference line RL1 (RL1-L1T).

9. The distance from upper first molar mesio-buccal cusp tip to reference line RL1 (RL1-U6).

10. The distance from lower first molar mesio-buccal cusp tip to reference line RL1 (RL1-L6).

11. The distance from point $A$ to reference line $R L 2\left(R L 2 \perp_{A}\right)$.

12. The distance from point $B$ to reference line RL2 $(R L 2 \perp-B)$.

13. The distance from upper incisor tip to reference line RL2 $(\mathrm{RL} 2 \perp \mathrm{U} 1 \mathrm{~T})$.

14. The distance from lower incisor tip to reference line RL2 $\left(\mathrm{RL} 2 \perp_{\mathrm{L}} 1 \mathrm{~T}\right)$.

15. The distance from upper first molar distal border to reference line RL2 (RL2」U6).

16. The distance from lower first molar distal border to reference line R2 (1RL2 ${ }_{\text {L6 }}$ ).

17. The distance from labia superiores to reference line RL2 (RL2 $\perp$ Lab.Sup.).

18. The distance from labia inferiores to reference line RL2 (RL2 $\perp_{\mathrm{Lab}}$ Inf.).

19. The distance from Pogonion soft tissue point to reference line RL2 (RL2 $\perp_{P g}$ soft tissue). 


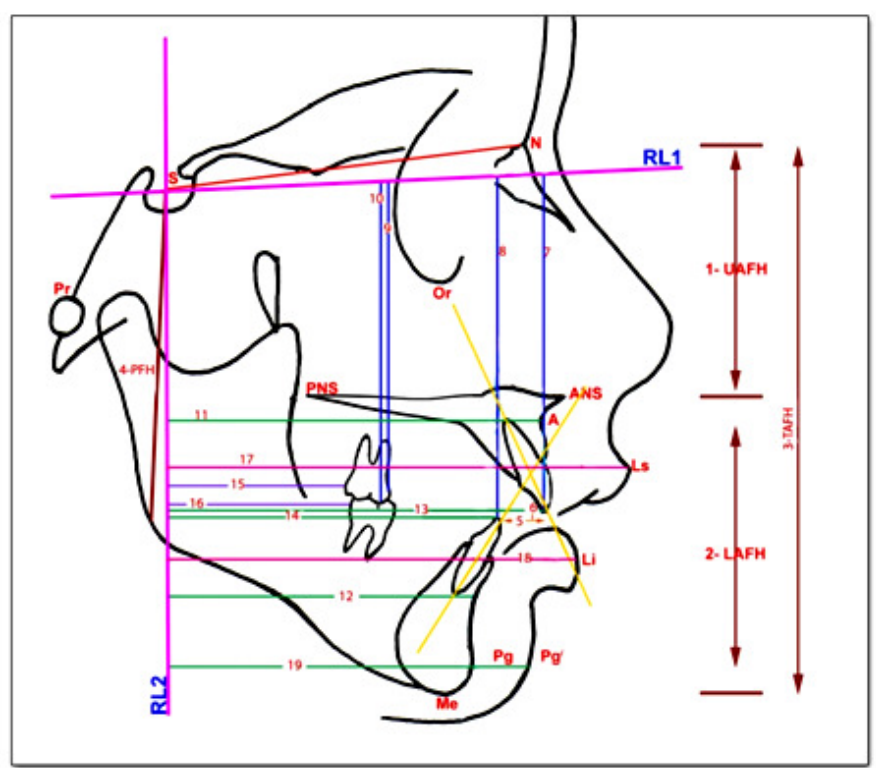

Figure 3 : cephalometric linear measurements.

$$
\begin{aligned}
& \text { 1-(UAFH). 10-(RL1-L6). } \\
& \text { (LAFH) } \quad 11-\left(\mathrm{RL} 2 \perp_{\mathrm{A}}\right) \text {. } \\
& \text { TAFH (N-Me). } \quad 12-(\text { RL } 2 \perp \text { B). } \\
& \text {-(PFH). 13-(RL2 } 14 \text { U1T). } \\
& \text { - Overjet. } 15-\left(\mathrm{RL} 2 \perp_{\mathrm{U} 6}\right) \\
& \text { 6-Overbite. } \quad 16-\left(1 \mathrm{RL}-2 \perp_{1.6}\right) \\
& \text { 7-(RLI-UIT). } 17-\left(\text { RL.2 } \perp_{\text {L ab.S }}\right. \text { up } \\
& \text { 8-(RL1-L1T) 18-(RL2 } \perp_{\text {Lab. Inf }) \text {. }} \\
& \text { 9-(RL1-U6). 19-(RL2 } \perp \text { Pg soft tissue) }
\end{aligned}
$$

\section{Airway Measurements (Figure4)}

The pharyngeal airway space was measured at three levels; upper, middle and lower. First a reference line perpendicular to RL1 plane was drawn .Upper Pharyngeal Air-Way Space( UPAS ) is the distance from PSP which is the PNS part of the soft palate to the posterior pharyngeal wall perpendicular to the reference line and the Middle Pharyngeal Air-Way Space (MPAS) is the distance from ESP which is the end of the soft palate to the posterior pharyngeal wall perpendicular to the reference line while, the Lower Pharyngeal Air-Way Space (LPAS) the distance between anterior and posterior pharyngeal wall perpendicular to the reference line at the level of the superior margin of the body of the hyoid bone (HB). 


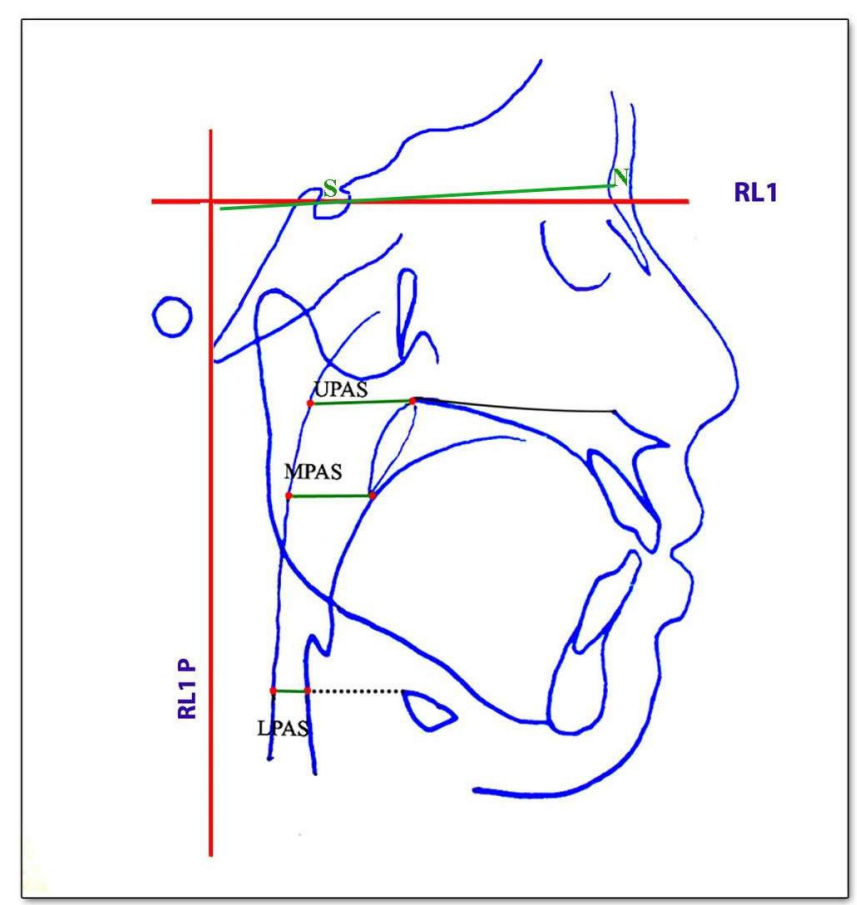

Figure (4): upper, middle and lower pharyngeal airway space (UPAS, MPAS and LPAS).

\section{Dental Cast Analysis (Figure5)}

Inter-molar and inter-canine widths were measured to quantify the changes in the anterior and posterior arch width of maxilla and mandible. Arch circumference and arch depth were also measured before insertion and after removal of the appliance and the obtained data were statistically analyzed. The maxillary and mandibular arch depth (AD), inter-canine width (ICW), inter-molar width (IMW) and arch circumference (AC) were measured using calipers ${ }^{\bullet}$ accurate to $0.1 \mathrm{~mm}$.

Arch depth (AD) was measured from the midpoint of the most labial aspect of the central incisors to the point bisecting the line connecting the mesial contacts of the first molars .Inter-canine width (ICW) was

\footnotetext{
- Digital dental caliper. Masel orthodontics. MASEL 1822 Aston Avenue Carlsbad, CA 92008 USA Ph: +(1) 80009862735 Fax: +(1) 80009962735
} 
Egyptian

Orthodontic Journal

measured between the cusp tips or estimated cusp tips when wear facets were present. Inter-molar width (IMW) was measured between the buccal fissures on the occlusal surfaces of both lower first molars (Yasuko Kuroda et al 2010). ${ }^{(21)}$

For all the study model parameters two measurements were taken for each parameter and averaged.

Arch circumference (AC): the sum of the distances measured from the mesial aspect of the right first permanent molar to the distal aspect of the right permanent lateral incisor, distal aspect of the right permanent lateral incisor to midline, midline to distal aspect of the left permanent lateral incisor and distal aspect of the left permanent lateral incisor to mesial aspect of the left first permanent molar (Osborn et al 1991). ${ }^{(22)}$

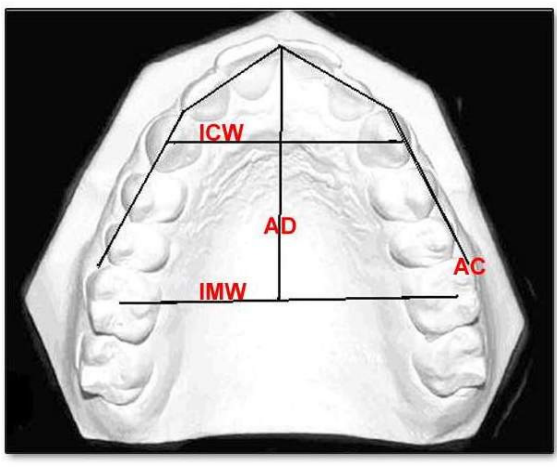

Figure (5 A)

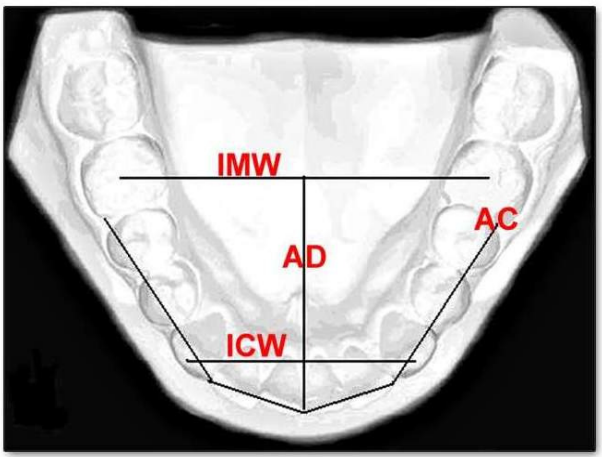

Figure (5 B)

Figure (5 A, B): Upper and lower models: inter-canine width (ICW), inter-molar width (IMW), arch depth (AD) and arch circumference (AC).

In order to reduce the method error, all measurements were performed twice with an interval of at least two weeks between the registrations. The mean value of the duplicate registrations was used in the final evaluation. For each variable, the mean, the slandered deviation was calculated. A student's t test for paired sample was used to assess the significance of skeletal, dental, soft tissue and pharyngeal airway changes produced by each appliance. For group comparisons, the student $t$ test for 
Egyptian

Orthodontic Journal

unpaired sample was utilized. The statistical significance was determined at the probability levels of $P . \leq 0.05$. All statistical calculations were carried out with SPSS 17.0" software.

\section{RESULTS}

All skeletal and dental changes obtained by both appliances are stable after four years with non significant difference but the stability of skeletal changes of twin force bite corrector is better than jasper jumper appliance which shows greater but still non significant skeletal changes. ANB increased by 0.3 degree and 1.9 degree for both appliances respectively and little non significant changes occurred in anterior and posterior facial height, also facial angle and mandibular plane angle are stable after four years of treatment for both appliances.

A significant difference was found regarding $\mathbf{U 1}$ to $\mathbf{F H}^{\circ}$ which increased by 5.7 degree and 7.05 degree for TFBC and JJ respectively. While $\mathrm{L} 1$ to $\mathrm{Mp}$ and inter-incisor angle showed non significant changes in both appliances. Also the soft tissue $\mathrm{H}$ angle , naso-labial angle , upper, middle and lower pharyngeal airway changes obtained by both appliances are stable with non significant differences for TFBC after four years compared with greater but still non significant changes for JJ appliances.

A significant increase was found regarding upper arch depth after four years of treatment with TFBC when compared with JJ appliance $(1.95 \mathrm{~mm}$ and $3.6 \mathrm{~mm})$ respectively. (P. value $\leq 0.05)$ and a highly significant increase was found regarding lower arch depth after four years of treatment with TFBC when compared with JJ appliance $(2 \mathrm{~mm}$ and $3.2 \mathrm{~mm}$ ) respectively. (P. value $<0.001)$. On the other hand upper and lower inter-canine and inter-molar width shows little non significant changes for both appliances.

\footnotetext{
*Statistical Package For Scientific Studies
} 


\section{Egyptian}

Orthodontic Journal

Table (1). Comparison of Stability of antro-posterior and vertical skeletal changes obtained with TFBC and JJ after 4 years

\begin{tabular}{|c|c|c|c|c|c|c|c|c|}
\hline \multirow[t]{2}{*}{ Parameters } & \multicolumn{2}{|c|}{ Post-TFBC } & \multicolumn{2}{|c|}{$\begin{array}{l}4 \text { years After } \\
\text { TFBC }\end{array}$} & \multirow{2}{*}{$\begin{array}{c}\text { Difference } \\
\text { TFBC after } \\
4 \text { years }\end{array}$} & \multirow{2}{*}{$\begin{array}{c}\text { Difference } \\
\text { jj after } 4 \\
\text { years }\end{array}$} & \multirow[t]{2}{*}{$\mathbf{t}$} & \multirow[t]{2}{*}{$\mathbf{p}$} \\
\hline & Mean & SD & Mean & SD & & & & \\
\hline SNA $^{\circ}$ & 82 & 2.47 & 82.5 & 2.58 & 0.5 & 0.7 & 0.442 & 0.663 \\
\hline $\mathrm{SNB}^{\circ}$ & 77.9 & 2.36 & 77.7 & 2.11 & $0.2-$ & -0.3 & $\cdot .201$ & 0.844 \\
\hline $\mathbf{A N B}^{\circ}$ & 4.1 & .94 & 4.4 & .68 & 0.3 & 1.9 & 0.392 & 0.704 \\
\hline $\mathrm{RL} \perp^{\perp} \mathrm{Amm}$ & 67 & 2.89 & 68.20 & 2.16 & 1.2 & 2.0 & 1.052 & 0.307 \\
\hline $\mathrm{RL} 2 \perp_{\mathrm{B}} \mathbf{~ m m}$ & 59.40 & 3.09 & 59 & 2.87 & -0.4 & -1 & 0.304 & 0.768 \\
\hline facial angle $^{\circ}$ & 84.7 & 3.29 & 84.4 & 3.02 & -0.3 & -0.6 & 0.209 & 0.384 \\
\hline $\mathrm{SN}$ to $\mathrm{Pg}^{\circ}$ & 76.9 & 1.87 & 76.45 & 1.36 & -0.45 & -0.8 & 0.617 & 0.546 \\
\hline FH to $\mathrm{SN}^{\circ}$ & 7.65 & 1.68 & 7.2 & 1.61 & -0.45 & -0.65 & 0.613 & 0.548 \\
\hline MP to $\mathrm{PP}^{\circ}$ & 30.45 & 6.13 & 31.1 & 4.36 & 0.65 & 0.65 & 0.269 & 0.788 \\
\hline MP to $\mathrm{SN}^{\circ}$ & 37.55 & 3.16 & 38 & 2.58 & 0.45 & 0.1 & 0.354 & 0.731 \\
\hline UAFH mm & 57.10 & 4.43 & 57.84 & 3.14 & 0.74 & 0.8 & 0.432 & 0.672 \\
\hline LAFH mm & 67.20 & 4.51 & 67.8 & 3.51 & 0.6 & 0.4 & 0.438 & 0.663 \\
\hline TAFH mm & 124.30 & 7.76 & 125.84 & 5.44 & 1.54 & 1.2 & 0.508 & 0.614 \\
\hline PFH mm & 75.90 & 5.3 & 75.54 & 2.65 & -0.36 & -0.6 & 0.189 & 0.849 \\
\hline
\end{tabular}

P. value $\leq 0.05^{*}$ (significant)

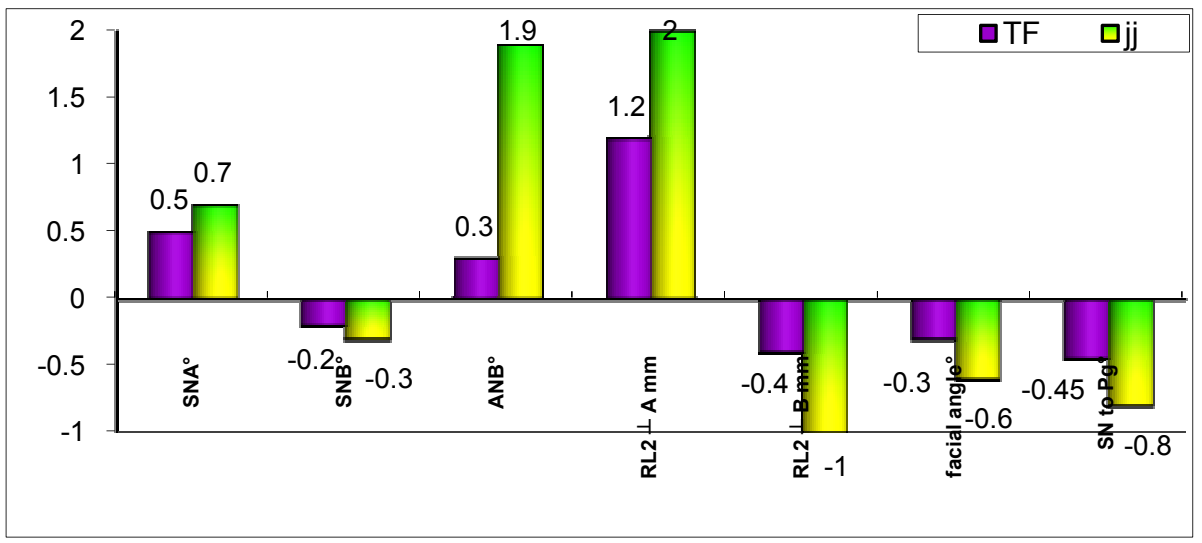

Fig (6 A): Comparison of Stability of antero-posterior skeletal changes obtained with TFBC and JJ after 4 year 


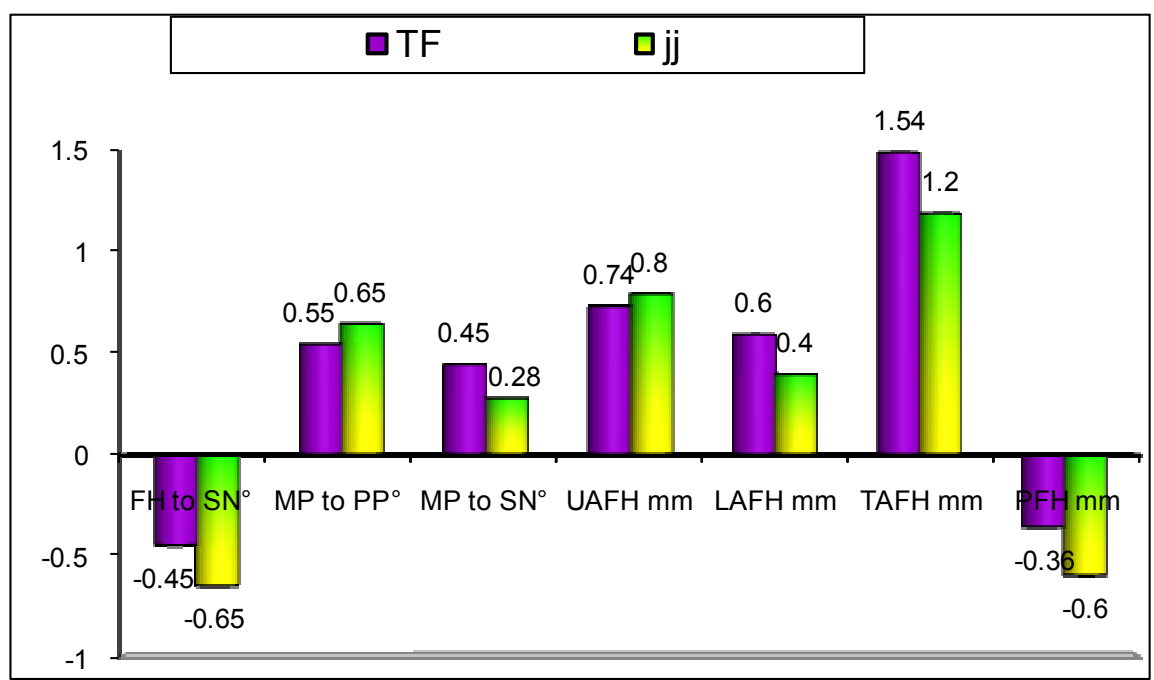

Fig (6 B): Comparison of Stability of vertical skeletal changes obtained with TFBC and JJ after 4 year

Table (2): Comparison of Stability of antero-posterior and vertical dental changes obtained with TFBC and JJ after 4 years

\begin{tabular}{|c|c|c|c|c|c|c|c|c|}
\hline \multirow{2}{*}{ Parameters } & \multicolumn{2}{|c|}{ Post- TFBC } & \multicolumn{2}{|c|}{$\begin{array}{c}4 \text { years After } \\
\text { TFBC }\end{array}$} & \multirow{2}{*}{$\begin{array}{c}\text { Difference } \\
\text { TFBC after } 4 \\
\text { years }\end{array}$} & \multirow{2}{*}{$\begin{array}{c}\text { Difference } \\
\text { jj after } 4 \\
\text { years }\end{array}$} & \multirow[t]{2}{*}{ t } & \multirow[t]{2}{*}{ p } \\
\hline & Mean & SD & Mean & SD & & & & \\
\hline Overjet & 1.5 & 1.43 & 2.1 & 1.11 & 0.6 & 1.6 & 1.052 & 0.308 \\
\hline $\mathrm{RL2} \perp \mathrm{U1T}$ mm & 70.70 & 2.78 & 71.7 & 1.92 & 1 & 1.3 & 0.939 & 0.362 \\
\hline RL2 $\perp^{-} \mathbf{L 1 T}$ mm & 70.9 & 3.05 & 70.6 & 2.57 & -0.3 & -0.6 & 0.242 & 0.815 \\
\hline $\mathrm{RL} 2 \perp \mathrm{U} 6 \mathrm{~mm}$ & 27 & 1.36 & 29 & 1.25 & 2 & 3.0 & 3.424 & 0.003 \\
\hline $\mathrm{RL} 2 \perp \mathbf{L 6} \mathbf{~ m m}$ & 32.90 & 2.64 & 32.10 & 2.15 & -0.8 & -1.1 & 0.742 & 0.467 \\
\hline Overbite mm & 0.80 & .75 & 2.1 & .96 & 1.3 & 1.35 & 3.374 & 0.003 \\
\hline $\mathrm{RL1} \stackrel{\perp}{ }{ }^{\mathrm{U} 1 \mathrm{~T}} \mathrm{~mm}$ & 77.40 & 3.53 & 78.60 & 2.28 & 1.2 & 1.6 & 0.904 & 0.378 \\
\hline $\mathrm{RL1}^{\perp} \perp_{\mathbf{L} 1 \mathrm{~T}} \mathrm{~mm}$ & 73.4 & 4.69 & 73 & 3.54 & 0.4 & -0.9 & 0.224 & 0.832 \\
\hline $\mathrm{RL1} \perp \mathrm{U6} \mathbf{~ m m}$ & 67.60 & 4.12 & 68.80 & 3.41 & 1.2 & 2 & 0.712 & 0.487 \\
\hline $\mathbf{R L 1} \perp \mathbf{L 6 ~ m m}$ & 67.60 & 4.49 & 68 & 3.68 & 0.4 & 0.64 & 0.219 & 0.829 \\
\hline
\end{tabular}

P. value $\leq 0.05^{*}$ (significant) 


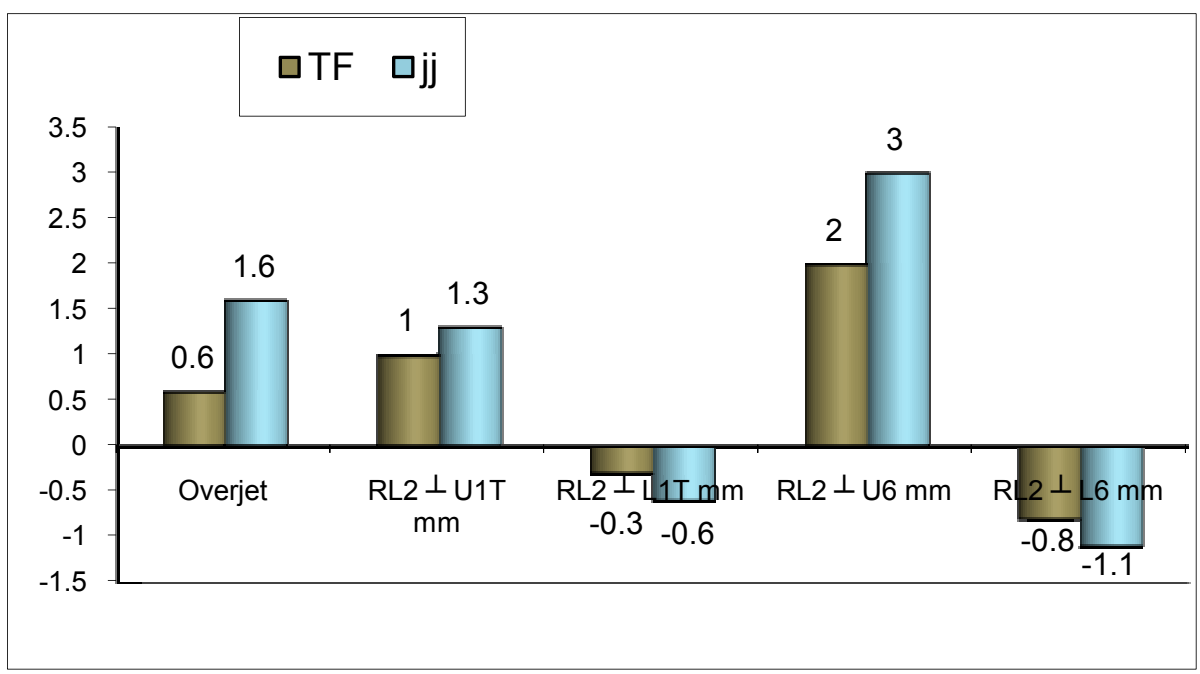

Fig (7A): Comparison of Stability of antero-posterior dental changes obtained with TFBC and JJ after 4 year.

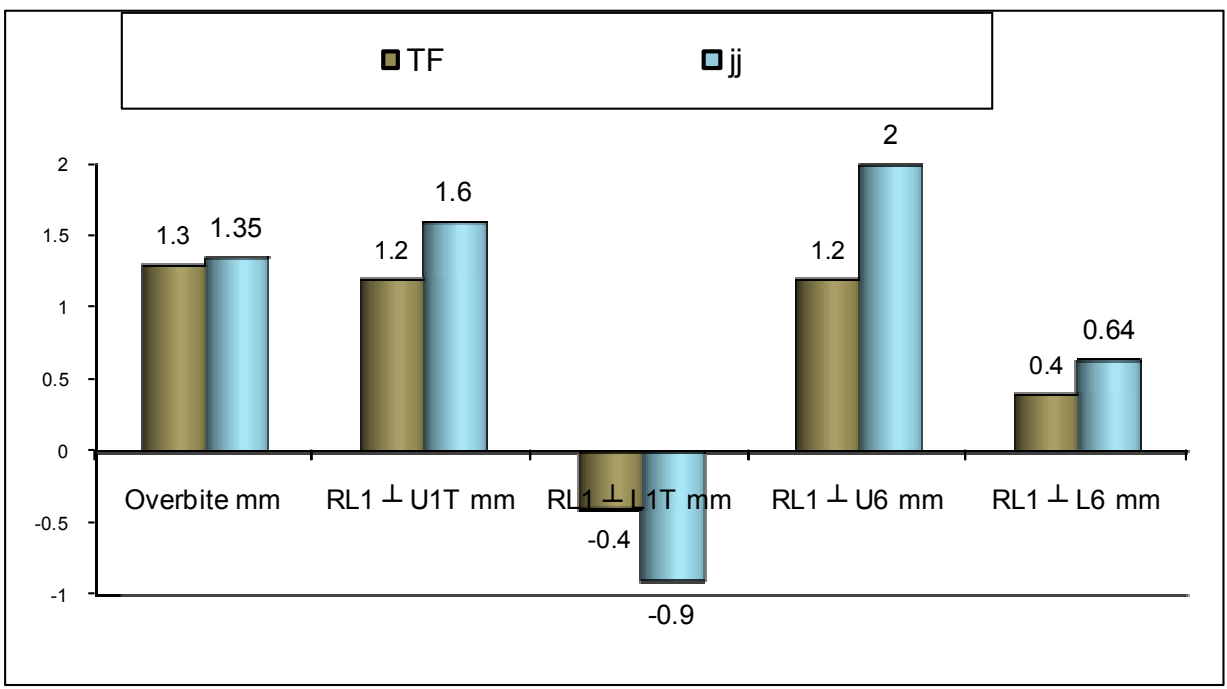

Fig (7B): Comparison of Stability of vertical dental changes obtained with TFBC and JJ after 4 year. 


\section{Egyptian \\ Orthodontic Journal}

Table(3 ): Comparison of Stability of angular changes of the incisors obtained with TFBC and JJ after 4 years

\begin{tabular}{|c|c|c|c|c|c|c|c|c|}
\hline \multirow{2}{*}{ Parameters } & \multicolumn{2}{|c|}{$\begin{array}{c}\text { Post-Twin } \\
\text { Force }\end{array}$} & \multicolumn{2}{|c|}{ After 4 years } & \multirow{2}{*}{$\begin{array}{c}\text { Difference } \\
\text { TFBC after } 4 \\
\text { years }\end{array}$} & \multirow{2}{*}{$\begin{array}{c}\text { Difference } \\
\text { jj after } 4 \\
\text { years }\end{array}$} & \multirow[t]{2}{*}{ t. test } & \multirow[t]{2}{*}{ P Value } \\
\hline & Mean & SD & Mean & SD & & & & \\
\hline $\mathrm{U} 1$ to $\mathrm{FH}^{\circ}$ & 108.40 & 3.74 & 114.1 & 2.14 & 5.7 & 7.05 & 5.704 & $0.001 * *$ \\
\hline L1 to $\mathrm{MP}^{\circ}$ & 105.80 & 4.70 & 102.30 & 3.62 & -3.5 & -4.8 & 1.869 & 0.078 \\
\hline U1 to $\mathrm{L1}^{\circ}$ & 121.75 & 5.42 & 121 & 3.54 & -0.75 & -1.25 & 0.373 & 0.718 \\
\hline
\end{tabular}

P. value $<0.05^{*}$ (significant)

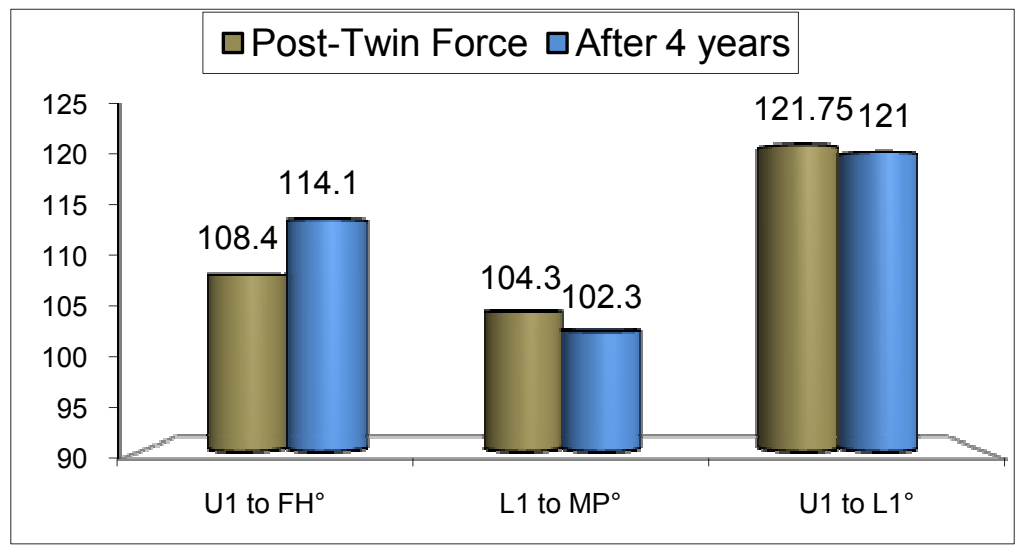

Fig (8 A): Comparison of Stability of angular changes of the incisors obtained with TFBC after 4 years

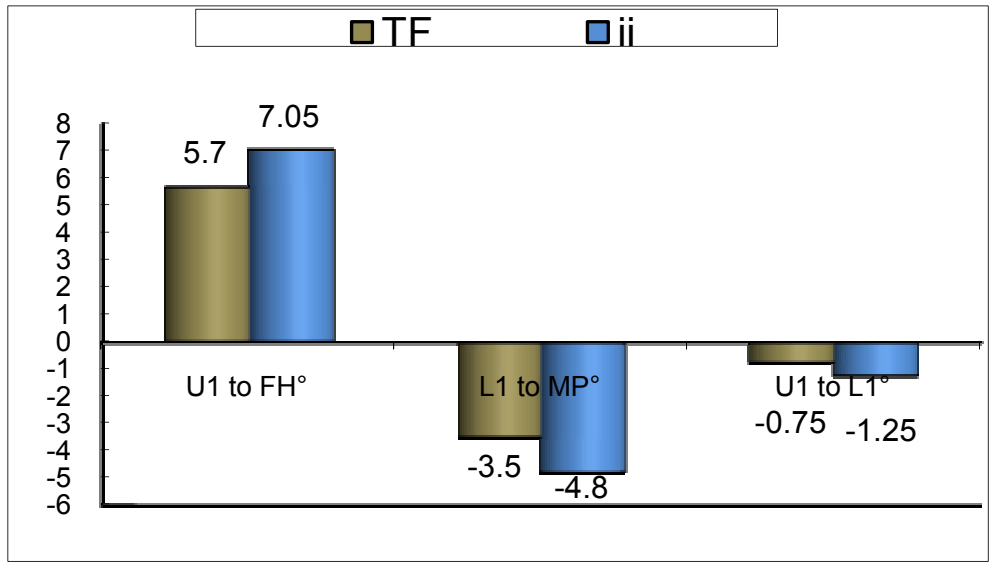

Fig (8 B): Comparison of Stability of angular changes of the incisors obtained with TFBC and JJ after 4 years

Volume 46-Decem6er 2014 


\section{Egyptian \\ Orthodontic Journal}

Table (4): Comparison of Stability of soft tissue changes obtained with TFBC and JJ after 4 years

\begin{tabular}{|c|c|c|c|c|c|c|c|c|}
\hline \multirow{2}{*}{ Parameters } & \multicolumn{2}{|c|}{$\begin{array}{l}\text { Post-Twin } \\
\text { Force }\end{array}$} & \multicolumn{2}{|c|}{ After 4 years } & \multirow{2}{*}{$\begin{array}{c}\text { Difference } \\
\text { TFBC after } 4 \\
\text { years }\end{array}$} & \multirow{2}{*}{$\begin{array}{c}\text { Difference } \\
\text { jj after } 4 \\
\text { years }\end{array}$} & \multirow[t]{2}{*}{ t. test } & \multirow[t]{2}{*}{ P Value } \\
\hline & Mean & SD & Mean & SD & & & & \\
\hline $\mathrm{RL}_{2} \perp_{\text {Lab.Superior }} \mathbf{m m}$ & 83.40 & 4.08 & 85 & 3.25 & 1.6 & 3.0 & 0.968 & 0.345 \\
\hline $\mathrm{RL} \stackrel{\perp}{\text { Lab. Inferior }} \mathbf{m m}$ & 87.85 & 5.65 & 87 & 4.75 & -0.85 & -1.91 & 0.364 & 0.719 \\
\hline $\mathrm{RL}_{2} \perp_{\mathrm{Pg} \text { Soft Tissue }} \mathrm{mm}$ & 73.30 & 7.62 & 72.6 & 6.91 & -0.7 & -1.60 & 0.218 & 0.832 \\
\hline H Angle ${ }^{\circ}$ & 16.40 & 3.23 & 17 & 2.47 & 0.6 & 0.9 & 0.474 & 0.646 \\
\hline Nasolabial Angle $^{\circ}$ & 112 & 8.41 & 109 & 8.65 & -3 & -6.0 & 0.793 & 0.442 \\
\hline UPAS mm & 15.74 & 4.66 & 16 & 3.84 & 0.26 & 0 & 0.144 & 0.893 \\
\hline MPAS mm & 13.49 & 1.82 & 13.51 & 1.25 & 0.02 & 0 & 0.033 & 0.977 \\
\hline LPAS mm & 12 & 3.14 & 11.5 & 3.10 & -0.5 & -1.0 & 0.359 & 0.724 \\
\hline
\end{tabular}

P. value $<0.05^{*}($ significant $)$

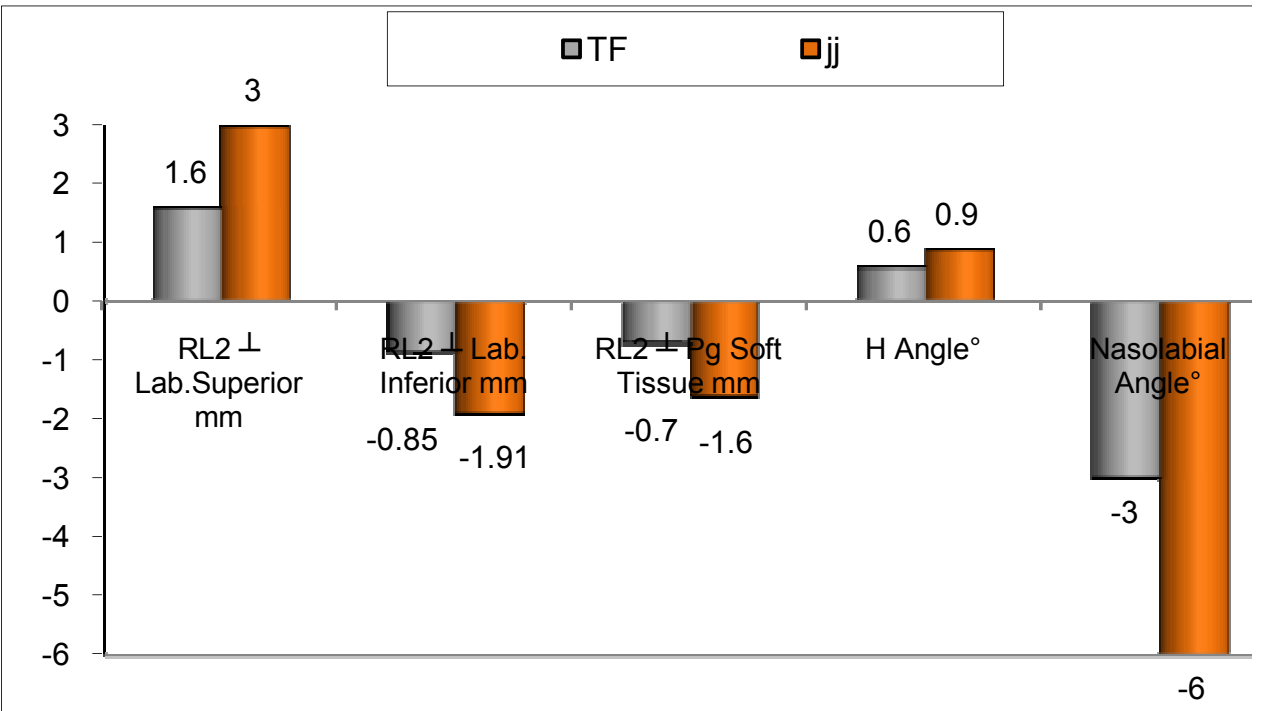

Fig (9 A): Comparison of Stability of soft tissue changes obtained with TFBC and JJ after 4 year

Volume 46 - December 2014 
Egyptian

Orthodontic Journal

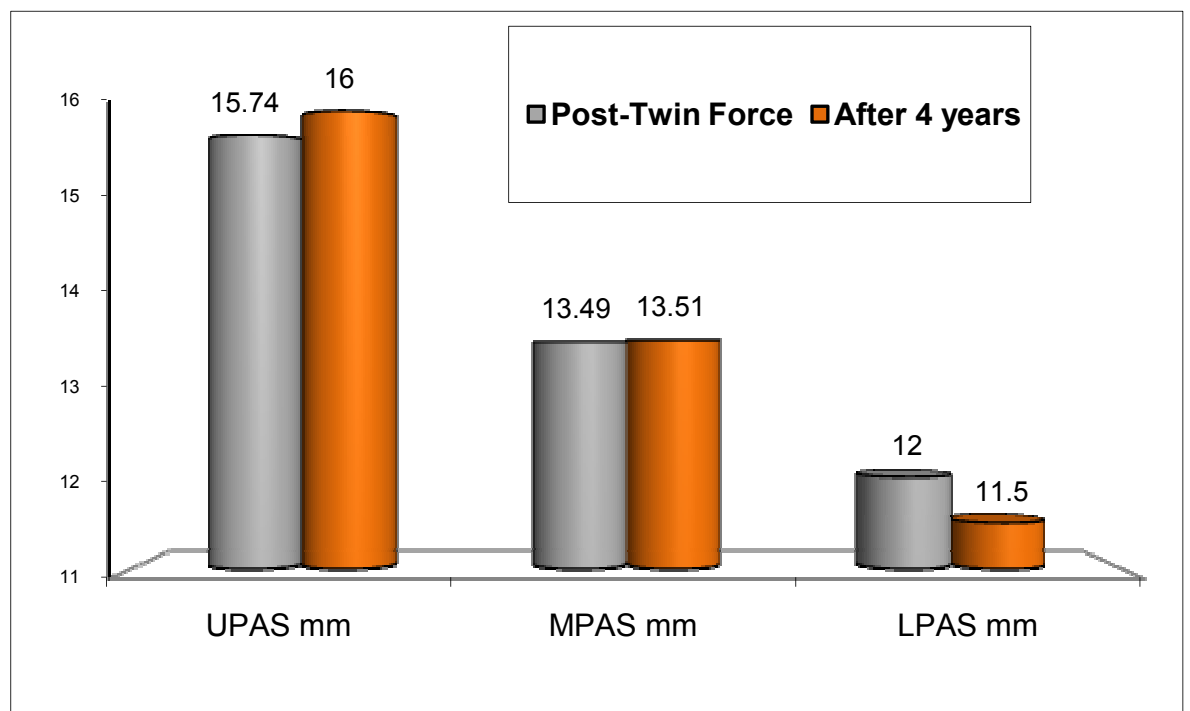

Fig (9 B): Comparison of Stability of pharyngeal airway changes obtained with TFBC after 4 year

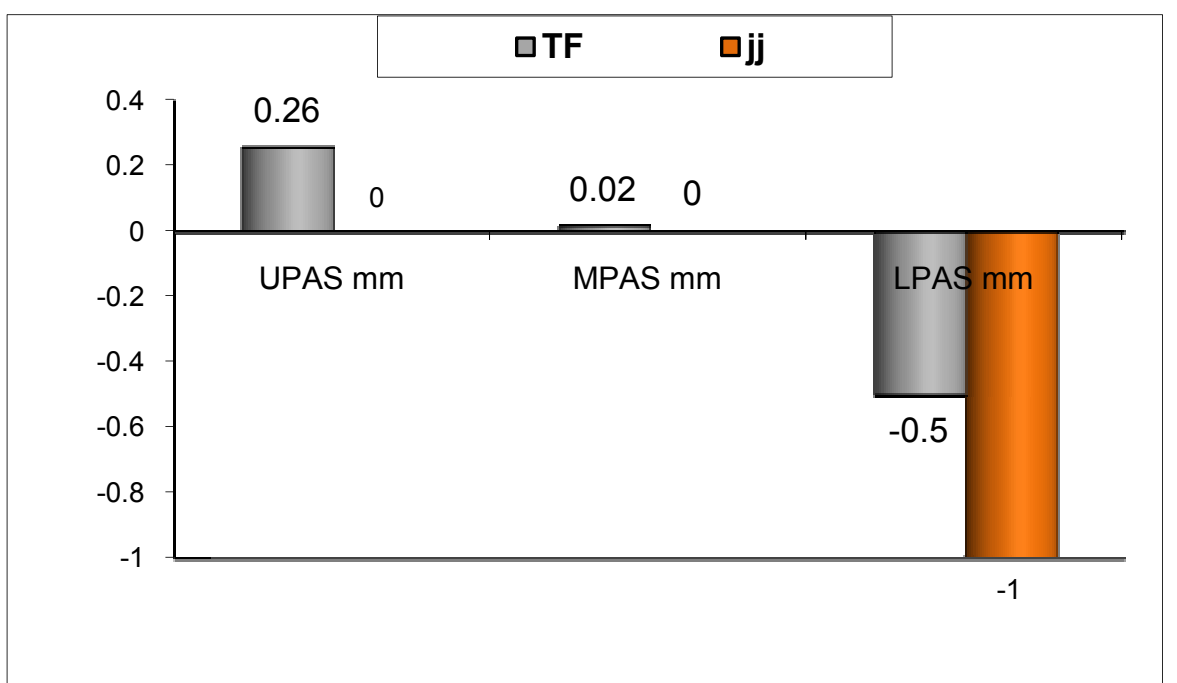

Fig (9C): Comparison of Stability of pharyngeal airway changes obtained with TFBC and $\mathrm{JJ}$ after 4 year

Volume 46 - December 2014 
Egyptian

Orthodontic Journal

Table (5). Comparison of Dental model changes obtained with TFBC and JJ after 4 years

\begin{tabular}{|l|c|c|c|c|c|c|c|c|}
\hline \multirow{2}{*}{ Parameters } & \multicolumn{2}{|c|}{$\begin{array}{c}\text { post-Twin } \\
\text { Force }\end{array}$} & \multicolumn{2}{|c|}{ After 4 years } & $\begin{array}{c}\text { Difference } \\
\text { TFBA after } \\
\text { 4 years }\end{array}$ & $\begin{array}{c}\text { Difference } \\
\text { jj after 4 } \\
\text { years }\end{array}$ & t. test & P Value \\
\cline { 2 - 9 } X & SD & $\mathbf{X}$ & SD & & & \\
\hline Upper inter-canine width & 35 & 2.60 & 35.75 & 2.01 & 0.75 & 0.1 & 0.719 & 0.479 \\
\hline Upper inter-molar width & 47 & 2.3 & 48.3 & 2.96 & 1.3 & 1.20 & 1.103 & 0.287 \\
\hline Upper arch depth & 28.05 & 1.64 & 30 & 1.87 & 1.95 & 3.60 & 2.484 & $0.023 *$ \\
\hline Upper arch circumference & 76.25 & 3.69 & 77.35 & 2.85 & 1.1 & 1.35 & 0.748 & 0.465 \\
\hline lower inter-canine width & 28.4 & 1.22 & 29.2 & 1.42 & 0.8 & 1.1 & 1.349 & 0.193 \\
\hline lower inter-molar width & 43 & 2.30 & 44 & 2.04 & 1.0 & 0.95 & 1.029 & 0.317 \\
\hline Lower arch depth & 21 & 1.22 & 23 & 1.12 & 2.0 & 3.2 & 3.824 & $0.001 * *$ \\
\hline Lower arch circumference & 65.4 & 5.19 & 67 & 3.54 & 1.6 & 1.4 & 0.809 & 0.431 \\
\hline
\end{tabular}

P. value $<0.05^{*}$ ( significant)

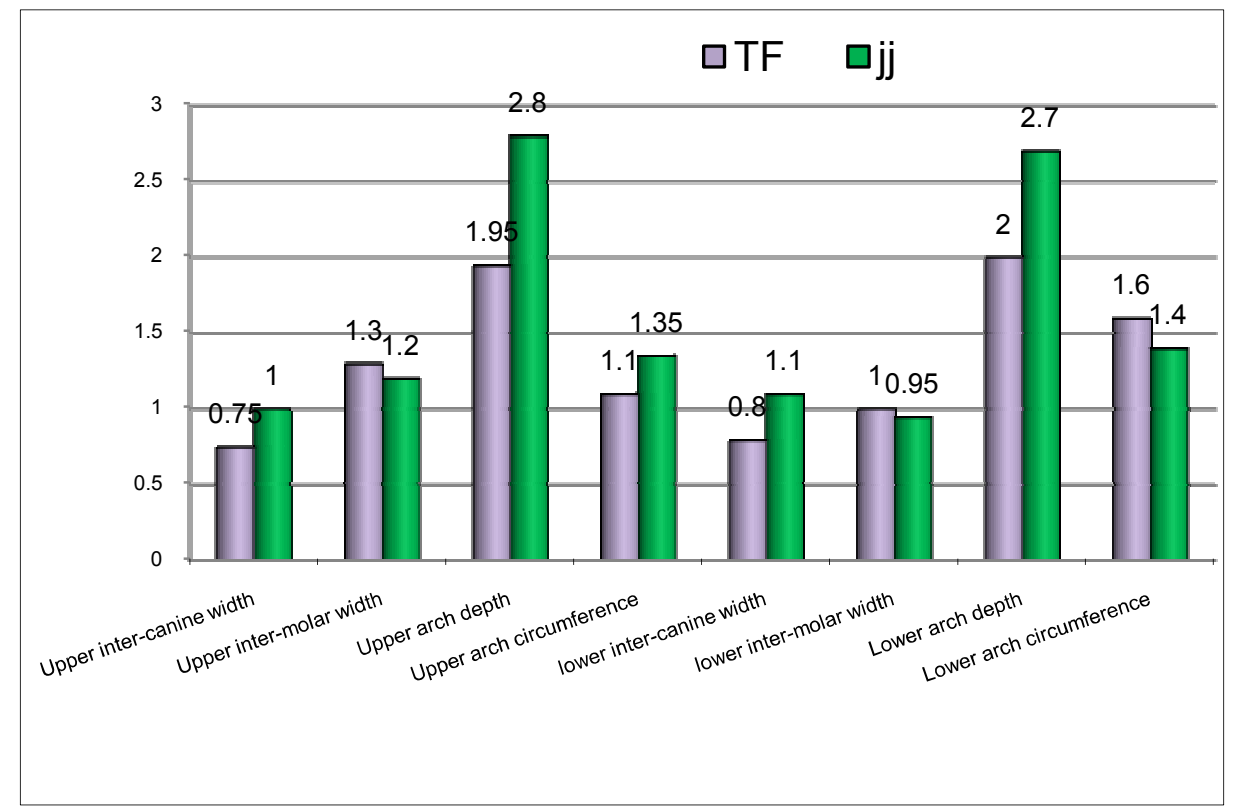

Figure (10). Comparison of Dental model changes obtained with TFBC and JJ after 4 years

Volume 46-Decem6er 2014 
Egyptian

Orthodontic Journal

\section{DISCUSSION}

Twin Force Bite Corrector (TFBC) considered a new fixed inter-maxillary appliance with a built-in constant force for Class II correction. The age group of the selected sample ranged from 13 years to 16 years as they treated by functional appliances four years ago this came in accordance with many authors ${ }^{(23-28)}$ as they stated that, the important key in Class II appliance therapy is the treatment timing and for optimal results, functional appliances should be utilized during or just after the peak growth period. Also Pancherz and $\operatorname{Hagg}^{(28,29)}$ and other au thors ${ }^{(26,3,31-33)}$ have shown that skeletal improvement with the Herbst appliance was related to somatic maturation.

In the present study both TFBC and JJ group was treated by non extraction protocol and result in good and stable results after four years from the end of treatment this came in accordance with Paquette DE et $\mathrm{al}^{(34)}$, Uhde MD et $\mathrm{al}^{(35)}$, Fidler $\mathrm{BC}$ et $\mathrm{al}^{(5)}$, Artun $\mathrm{J}$, et $\mathrm{al}^{(36)}$, Elms TN et $\mathrm{al}^{(37)}$, Birkeland $\mathrm{K}$ et al ${ }^{(38)}$ and Leonardo $\mathrm{T} \mathrm{C}$ et $\mathrm{al}^{(39)}$.

A slight non significant increase in overjet and overbite and slight proclination of lower incisors was found, this came in accordance with Ashok Karad et $\mathrm{al}^{(40)}$. Also our result agreed with Hansen $\mathrm{K}$ et $\mathrm{al}^{(41)}$ who studied the stability of the Herbst appliance. In the present study there were a non significant difference between TFBC and JJ regarding antero-posterior and vertical skeletal changes but in JJ group ANB angle increased by 1.9 degree while in TFBC group increased by 0.3 degree, point A become more forward and point $\mathrm{PG}$ become more backward in JJ group than TFBC group. This came in accordance with Aditya Chhibber et $\mathrm{al}^{(42)}$ who found stable post-treatment occlusions with the twin force bite corrector two to seven years after treatment.

A similar result to the present study was obtained by Hansen $\mathrm{K}$ et $\mathrm{al}^{(43)}$, Harres $\mathrm{EF}^{(44)}$, Tibana RH et $\mathrm{al}^{(45)}$ and Tesiopas $\mathrm{N}$ et al ${ }^{(46)}$, all stated that the changes was negligible and related to normal growth. Also the findings of the present study agreed with Giorgio Cacciatore et $\mathrm{al}^{(47)}$ for Forsus appliance after the end of treatment by 2 years . A similar result was obtained by Darwin Vaz et $\mathrm{al}^{(48)}$. 
Egyptian

Orthodontic Journal

In the present study overjet increased by $1.6 \mathrm{~mm}$ in $\mathrm{JJ}$ and $0.6 \mathrm{~mm}$ in TFBC but still non significant difference, also upper incisor tip become more forward in JJ group than TFBC group, this came in accordance with Madone and Ingervall ${ }^{(49)}$ as they reported partial relapse of the molar relationships. Also Uhde and colleagues ${ }^{(35)}$ and Hellekant and colleagues ${ }^{(50)}$ have also reported minor relapse of molar relationships and overjet in treated cases.

All dental measurements shows non significant changes after four years these findings came in accordance with previous studies for the MARA appliance as Siara-Olds et al. ${ }^{(51)}$ and Ghislanzoni et al. ${ }^{(52)}$. In the present study the over bite increased by $1.3 \mathrm{~mm}$ this results agreed with Simons ME et al ${ }^{(53)}$ Little RM et $\mathrm{al}^{(54)}$ and Uhde MD et $\mathrm{al}^{(35)}$.

Regarding the angular position of the upper and lower incisors relative to each other's and to FH and MP planes a highly significant difference was found in the position of the upper incisors relative to $\mathrm{FH}$ plane in TFBC group after 4 years of treatment as it increased 5.7 degrees these results came in accordance with Magnhild Lerstøl et al ${ }^{(55)}$ for combined activator-headgear treatment.

All soft tissue changes shows non significant changes after 4 years but labia superiors moved forward and labia inferiors moves backward in JJ group greater than TFBC group, the mandibular incisors were proclined during treatment and demonstrated similar trend in post-treatment period as well this came in accordance with the findings of Paquette DE et $\mathrm{al}^{(36)}$, Elms T et al $1996^{(37)}$, Schulhof et $\mathrm{al}^{(56)}$ and Shields TE et al (57).

The widening effect of both TFBC and JJ appliances on upper, middle and lower pharyngeal airway remain stable after 4 years with little decrease in LPAW by $0.5 \mathrm{~mm}$ in TFBC group and $1 \mathrm{~mm}$ in JJ group which considered insignificant changes these result came in accordance with Hänggi MP et $\mathrm{al}^{(58)}$ for activator-headgear and fixed appliance treatment.

In the present study a highly significant difference regarding the lower arch depth and a significant difference regarding upper arch depth after four years of treatment with TFBC appliance these finding agreed 
with Hans Pancherz et $\mathrm{al}^{(59)}$ and Moyers $\mathrm{RE}^{(60)}$ as they reported that the mandibular inter-molar arch width normally increases with age.

In contrast to the result of the present study Harris ${ }^{(44)}$ and Tsiopas et $\mathrm{al}^{(46)}$ reported marked decrease in the mandibular inter-canine arch widths this may be due to the difference in the period of study. Also in contrast to the results of the present study Glenn $\mathrm{G}$ et $\mathrm{al}^{(61)}$ and Thilander $\mathrm{B}^{(13)}$ found that Maxillary arch length was decreased during treatment, due to up righting and retraction of incisors. The mandibular arch length was maintained during the course of treatment. However, the arch lengths decreased in the post-retention stage. This also supports the concept of decrease in arch length consequent to the anterior component of force that tends to cause a mesial drift of the posterior teeth with time and the increase of the arch length of the present study due to slight proclination of upper and lower incisors and slight backward movement of the lower molars in the post-retention stage.

\section{CONCLUSIONS}

All skeletal, dental, soft tissue and pharyngeal airway changes obtained by both appliances are stable after four years with non significant difference while ANB angle, upper and lower arch depth shows less stable with significant increase after four years of treatment. The stability of TFBC is better than JJ appliance. Both appliances are effective for treatment of developing Class II division 1 malocclusion.

\section{REFERENCES}

1. Proffit WR, Fields HW, Moray LJ 1998. Prevalence of malocclusion and orthodontic treatment need in the United States: estimates from the nhanes-III survey. Int J Adult Orthod Ortho gnath Surg. 13:97-106.

2. McNamara JA Jr 1981. Components of Class II malocclusion in children 8-10 years of age. Angle Orthod. 51(3):177-202.

3. McNamara JA Jr, Bookstein F, Shaughnessy T 1985. Skeletal and dental changes following functional regulator therapy on Class II patients. Am J Orthod. 88(2):91-110. 
Egyptian

Orthodontic Journal

4. Herzberg R 1973. A cephalometric study of Class II relapse. Angle Orthodontist,43: 112-118.

5. Fidler B C, Årtun J, Joondeph D R, Little R M 1995. Long-term stability of Angle Class II, division 1 malocclusions with successful occlusal results at end of active treatment. American Journal of Orthodontics and Dento facial Orthopedics, 107: 276-285.

6. Nelson C, Harkness M, Herbison P. 1993. Mandibular changes during functional appliance treatment. Am J Orthod Dento facial Orthop.; 104:153-161.

7. Patel HP, Moseley HC, Noar JH. 2002. Cephalometric determinants of successful functional appliance therapy. Angle Orthod. 72:410-417.

8. Cozza P, Baccetti T, Franchi L, De Toffol L, McNamara JA Jr. 2006. Mandibular changes produced by functional appliances in Class II malocclusion: a systematic review. Am J Orthod Dentofacial Orthop; 129:599.e1-12.

9. Schaefer AT, McNamara JA Jr, Franchi L, Baccetti T. 2004. A cephalometric comparison of treatment with the twin-block and stainless steel crown Herbst appliance followed by fixed appliance therapy. Am J Orthod Dento facial Orthop.; 126:7-15.

10. Ritto AK, Ferreira AP. 2000 Fixed functional appliances-a classification. Funct Orthod.; 17:2-32.

11. Jasper JJ, McNamara JA Jr. 1995 The correction of inter-arch malocclusions using a fixed force module. Am J Orthod Dento facial Orthop; 108:641-650.

12. Küc,ükkeles, N, Ilhan I, Orgun IA. 2007. Treatment efficiency in skeletal Class II patients treated with the jasper jumper. Angle Orthod. 77:449-456.

13. Thilander B 2000. Orthodontic relapse versus natural development. Am J Orthod Dento facial Orthop. 117:562-3.

14. Ormiston J P, Huang G J, Little R M, Decker J D, Seuk G D 2005. Retrospective analysis of long-term stable and unstable orthodontic treatment outcomes. American Journal of Orthodontics and Dento facial Orthopedics 128: 568-574. 
15. Lerstøl M, Torgot O, Vandevska-Radunovic V 2010. Long-term stability of dentoalveolar and skeletal changes after activatorheadgear treatment. European Journal of Orthodontics. 32: 28-35.

16. Litowitz R. 1948. A study of the movements of certain teeth during and following orthodontic treatment. Angle Orthod.; 18:113-31.

17. Melrose C, Millett D T 1998. A perspective on orthodontic retention. American Journal of Orthodontics and Dento facial Orthopedics 113: 507-514.

18. Nanda R, Burzin J, Kim J M 1993. Factors influencing the stability of orthodontically treated dentitions. In: Hösl E, Baldauf A (eds). Retention and long-term stability. 8th International Conference for Orthodontists Hüthig, Heidelberg, pp. 41-46

19. Pancherz H 1991.The nature of Class II relapses after Herbst appliance treatment: a cephalometric long-term investigation. American Journal of Orthodontics and Dento facial Orthopedics 100: 220-233.

20. Nalbantgil D, Arun T, Sayınsu K and Isik F 2005. Skeletal, dental, and soft-tissue changes induced by the Jasper Jumper appliance in late adolescence. Angle Orthod ; 75:426-436.

21. Kurodaa Y, Kurodab S, Richard G. Alexander C and Tanakad E 2010. Adult Class 111 Treatment Using a J-Hook Headgear to the Mandibular Arch. Angle Orthod ; 80:336-343.

22. Osborn W, Nanda R and Currier G F 1991. Mandibular arch perimeter changes with lip bumper treatment. Am J Orthod Dentofac Orthop; 99:6: 527-32.

23. Jeff Rothenberg, Dmd Eric S. Campbell, Dds, Mds Ravindra Nanda 2004. Class II Correction with the Twin Force Bite Corrector, BDS, MDS, PHD JCO, 232-240.

24. Franchi, L.; Baccetti, T.; and McNamara, J.A. Jr. 2000. Mandibular growth as related to cervical vertebral maturation and body height, Am. J. Orthod. 118:335-340. 
25. Baccetti, T.; Franchi, L.; and McNamara, J.A. Jr. 2002. An improved version of the cervical vertebral maturation (CVM) method for the assessment of mandibular growth, Angle Orthod. 72:316- 323.

26. O'Reilly, M. and Yanniello, G.J. 1988. Mandibular growth changes and maturation of cervical vertebrae: A longitudinal cephalometric study, Angle Orthod. 58:179-184.

27. Malmgren, O.; Omblus, J.; Hagg, U.; and Pancherz, H. 1987. Treatment with an orthopedic appliance system in relation to treatment intensity and growth periods: A study of initial effects, Am. J. Orthod. 91:143-151.

28. Pancherz, H. and Hagg, U. 1985. Dentofacial orthopedics in relation to somatic maturation: An analysis of 70 consecutive cases treated with the Herbst appliance, Am. J. Orthod. 88:273-297.

29. Hagg, U. and Pancherz, H. 1988. Dento-facial ortho-pedics in relation to chronological age, growth period and skeletal development: An analysis of 72 male patients with Class II division I malocclusion treated with the Herbst appliance, Eur. J. Orthod.10:169-176.

30. Hunter, C.J. 1966.The correlation of facial growth with body height and skeletal maturation at adolescence, Angle Orthod. 36:44-54.

31. Pancherz, H. and Fackel, U. 1990. The skeletofacial growth pattern pre- and post-dento facial orthopaedics: A long-term study of Class II malocclusions treated with the Herbst appliance, Eur. J. Orthod. 12:209-218.

32. Von Bremen, J. and Pancherz, H. 2002. Efficiency of early and late Class II division I treatment, Am. J. Orthod. 121:31-37.

33. Baccetti, T.; Franchi, L.; Toth, L.R.; and McNamara, J.A. Jr. 2000. Treatment timing for Twin-block therapy, Am. J. Orthod. 118:159-170.

34. Paquette DE, Beattie JR, Johnston LE Jr 1992. A long-term comparison of nonextraction and premolar extraction edgewise therapy in "borderline" Class II patients. Am J Orthod Dento facial Orthop. Jul; 102:1-14. 
Egyptian

Orthodontic Journal

35. Uhde MD, Sadowsky C, BeGole EA. 1983 Long-term stability of dental relationships after orthodontic treatment. Angle Orthod. Jul; $53: 240-52$.

36. Artun J, Garol JD, Little RM 1996. Long-term stability of mandibular incisors following successful treatment of Class II, division 1, malocclusions. Angle Orthod.; 66:229-38.

37. Elms TN, Buschang PH, Alexander RG. 1996. Long-term stability of Class II, division 1, non extraction cervical face-bow therapy: I. Model analysis. Am J Orthod Dentofacial Orthop. Mar; 109:271-6.

38. Birkeland K, Furevik J, Boe OE, Wisth PJ. 1997. Evaluation of treatment and post-treatment changes by the PAR Index. Eur J Orthod. Jun; 19:279-88.

39. Leonardo Tavares Camardella, Guilherme Janson, Janine Della Valle Araki, Marcos Roberto de Freitas, Arnaldo Pinzan 2010. Influence of the extraction protocol of two maxillary premolars on the occlusal stability of Class II treatment Dental Press J Orthod July-Aug; 15:43-5.

40. Ashok Karad, Vishal Dhanjani, Vijay Bagul Smile Care, Bandra (West), Mumbai, 2013. Twenty -year post-treatment assessment of class II division 1 malocclusion treated with non-extraction approach India APOS Trends in Orthodontics January Vol 3 Issue 1

41. Hansen K, Pancherz H, Hagg U. 1991. Long-term effects of the Herbst appliance in relation to the treatment growth period: a cephalometric study. Eur J Orthod.; 13:471-81.

42. Aditya Chhibber, Bds, Mds Madhur Upadhyay, Bds, Mds Flavio Uribe, Dds, Mds Ravindra Nanda, 2010. Long-term stability of class II correction with the twin force bite corrector BDS, MDS, PHD JCO, $6: 363$ - 376 .

43. Hansen K, Koutsonas TG, Pancherz H. 1997. Long-term effects of Herbst treatment on the mandibular incisor segment: a cephalometric and biometric investigation. Am J Orthod Dento facial Orthop; 112:92-103. 
Egyptian

Orthodontic Journal

44. Harris EF. 1997 A longitudinal study of arch size and form in untreated adults. Am J Orthod Dentofacial Orthop; 111:419-27.

45. Tibana RH, Palagi LM, Miguel JA. 2004. Changes in dental arch measurements of young adults with normal occlusion-a longitudinal study. Angle Orthod; 74:618-23.

46. Tsiopas N, Nilner M, Bondemark L, Bjerklin KA. 201340 years follow-up of dental arch dimensions and incisor irregularity in adults. Eur J Orthod; 35:230-5.

47. Giorgio Cacciatorea; Luis Tomas Huanca Ghislanzonib; Lisa Alvetroc; Veronica Giuntinid; Lorenzo Franchie . 2014. Treatment and post-treatment effects induced by the Forsus appliance A controlled clinical study. Angle Orthod; 84:1010-1017.

48. Darwin Vaz de Lima1, Karina Maria Salvatore de Freitas2, Marcos Roberto de Freitas3, Guilherme Janson3, José Fernando Castanha Henriques3, Arnaldo Pinzan4 2013. Stability of molar relationship after non-extraction Class II malocclusion treatment Dental Press J Orthod. Mar-Apr; 18:42-54.

49. Madone, G. and Ingervall, B. 1984. Stability of results and function of the masticatory system in patients treated with the Herren type of activator, Eur. J. Orthod. 6:92-106.

50. Hellekant, M.; Lagerstrm, L.; and Gleerup, A. 1989. Overbite and overjet correction in a Class II, division 1 sample treated with Edgewise therapy, Eur. J. Orthod. 11:91-106.

51. Lavergne, J. and Petrovic, A. 1983. Discontinuities in occlusal relationship and the regulation of facial growth. A cybernetic view, Eur. J. Orthod. 5:269-278.

52. Ghislanzoni LT, Toll DE, Defraia E, Baccetti T, Franchi L. 2011. Treatment and post-treatment outcomes induced by the mandibular advancement repositioning appliance; a controlled clinical study. Angle Orthod. 81:684-691. 
53. Little RM, Wallen TR, Riedel RA. 1981. Stability and relapse of mandibular anterior alignment-first premolar extraction cases treated by traditional Edgewise orthodontics. Am J Orthod. Oct; 80:349-65.

54. Simons ME, Joondeph DR. 1973. Change in overbite: a ten-year post-retention study. Am J Orthod. Oct; 64:349-67.

55. Magnhild Lerstøl, Oystein Torget, Vaska Vandevska-Radunovic 2010. Long-term stability of dentoalveolar and skeletal changes after activator-headgear treatment. Eur J Orthod Feb 28;32:28-35.

56. Schulhof RJ, Allen RW, Walters RD, Dreskin M. 1977. The mandibular dental arch: Part I, lower incisor position. Angle Orthod 47:280-7.

57. Shields TE, Little RM, Chapko MK. 1985. Stability and relapse of mandibular anterior alignment: a cephalometric appraisal of first premolar extraction cases treated by traditional edgewise orthodontics. Am J Orthod; 87:27-38.

58. Hänggi MP1, Teuscher UM, Roos M, Peltomäki TA 2008. Longterm changes in pharyngeal airway dimensions following activatorheadgear and fixed appliance treatment. Eur J Orthod. Dec; 30:598605.

59. Hans Pancherz,a Krister Bjerklin,b Birgitta Lindskog-Stokland,c and Ken Hansend Giessen, Germany, and Malm€o and Gothenburg 2014. Thirty-two-year follow-up study of Herbst therapy: A biometric dental cast analysis, Am J Orthod Dento facial Orthop; 145:15-27.

60. Moyers RE, van der Linden FPGM, Riolo ML, McNamara JA. 1976. Standards of human occlusal development. Monograph 5. Craniofacial Growth Series. Ann Arbor: Center of Human Growth and Development; University of Michigan.

61. Glenn G, Sinclair P, Alexander R. 1987 nonextraction orthodontic therapy: A Post treatment dental and skeletal stability. Am J Orthod Dento facial Orthop; 92:321-8. 